\title{
Unnatural Cycles: Anthropogenic Disruption to Health and Planetary Functions
}

\author{
Gillian Gibson ${ }^{1, *}$ and Alex G Stewart ${ }^{2}$ \\ Gibson Consulting and Training, Tarporley, Cheshire CW6 0JH, UK; gillian@gbgibson.com \\ 2 College of Life and Environmental Sciences, University of Exeter, Exeter EX4 4RJ, UK; dragonsteeth@doc- \\ tors.org.uk \\ * Correspondence: gillian@gbgibson.com
}

\begin{abstract}
Natural cycles underpin the very stuff of life. In this commentary we consider unnatural cycles: that is, anthropogenic activities which have a circularity, but whose nature is to have a detrimental effect on human health, exacerbating existing problems. Natural cycles have feedback loops, some of which have recently come to light, with an understanding that everything is connected in some way. In health, feedback loops are imperative in homeostatic mechanisms. However, in the unnatural cycle the feedback loops serve to reinforce (and in some cases amplify) negative problems. We offer a commentary on an unnatural cycle moving from air quality to lung function and back to air quality; we call this the lung disease unnatural cycle. We suggest where links occur, and where wider consideration of interactions between various disciplines can lead to breaking this unnatural (or vicious) cycle, changing it to a healthy cycle where individual health can be improved, along with better global scale outcomes. We suggest that many activities within this unnatural cycle occur within silos. However, the improved cycle incorporates joint activities at geological, health, and financial levels, to the mutual benefit of all, breaking the unnatural cycle, and improving health, life and financial costs.
\end{abstract}

Keywords: natural cycles; air pollution; asthma; chronic obstructive airways disease; mining; sustainability; circular economy

\section{Introduction}

Geologists and biologists are familiar with natural cycles, such as the hydrological and nitrogen cycles. Many others will be familiar with the carbon cycle, given the current high profile of carbon and the need to reduce the atmospheric burden of carbon dioxide and other carbon-based global heating gases.

As the name implies, there is an expectation that natural cycles operate in a returning and recurring manner. For example, within the phosphorous cycle rocks weather naturally, becoming part of the soil structure, and phosphorous is either absorbed by growing plants or leached into aquatic systems. Once in the aquatic phase, phosphorous is absorbed by animals for construction of exo- or endo-skeletons. On the death of these organisms, the phosphorous becomes a part of the deposition process and is incorporated into the next generation of rock, through diagenesis and lithification.

Anthropogenic interference in this cycle can push it out of equilibrium. This includes abstraction of phosphate for industrial use as fertiliser, detergent, etc. As a consequence of these human activities, the phosphorus cycle is currently operating outside of the intended planetary boundaries: extensive mining has massively scarred mining localities; reserves are in steep decline; and use as an active ingredient in detergent and as fertiliser has led to eutrophication of water bodies.

In this concept paper we consider unnatural cycles, using an illustrative cycle. Whereas natural cycles should be maintained in dynamic equilibrium at all times in order 
to maintain environmental stability and animal and plant health, an unnatural cycle is a damaging cycle, usually of anthropogenic origin, which deserves to be broken in order to improve environmental stability and health at any or all levels from the local to the global.

Furthermore, we suggest that an unnatural cycle is one in which an action at one level has repercussions, usually negative, at many other levels within and without the cycle. Policy change, enforcement of regulations (or in some cases, development of regulatory frameworks), and co-ordinated approaches, as well as collaboration, will be required to achieve this outcome. These approaches are already recognised as required to prevent destruction of natural cycles. It should be possible to see the benefits of disruption of unnatural cycles at economic, social and environmental levels.

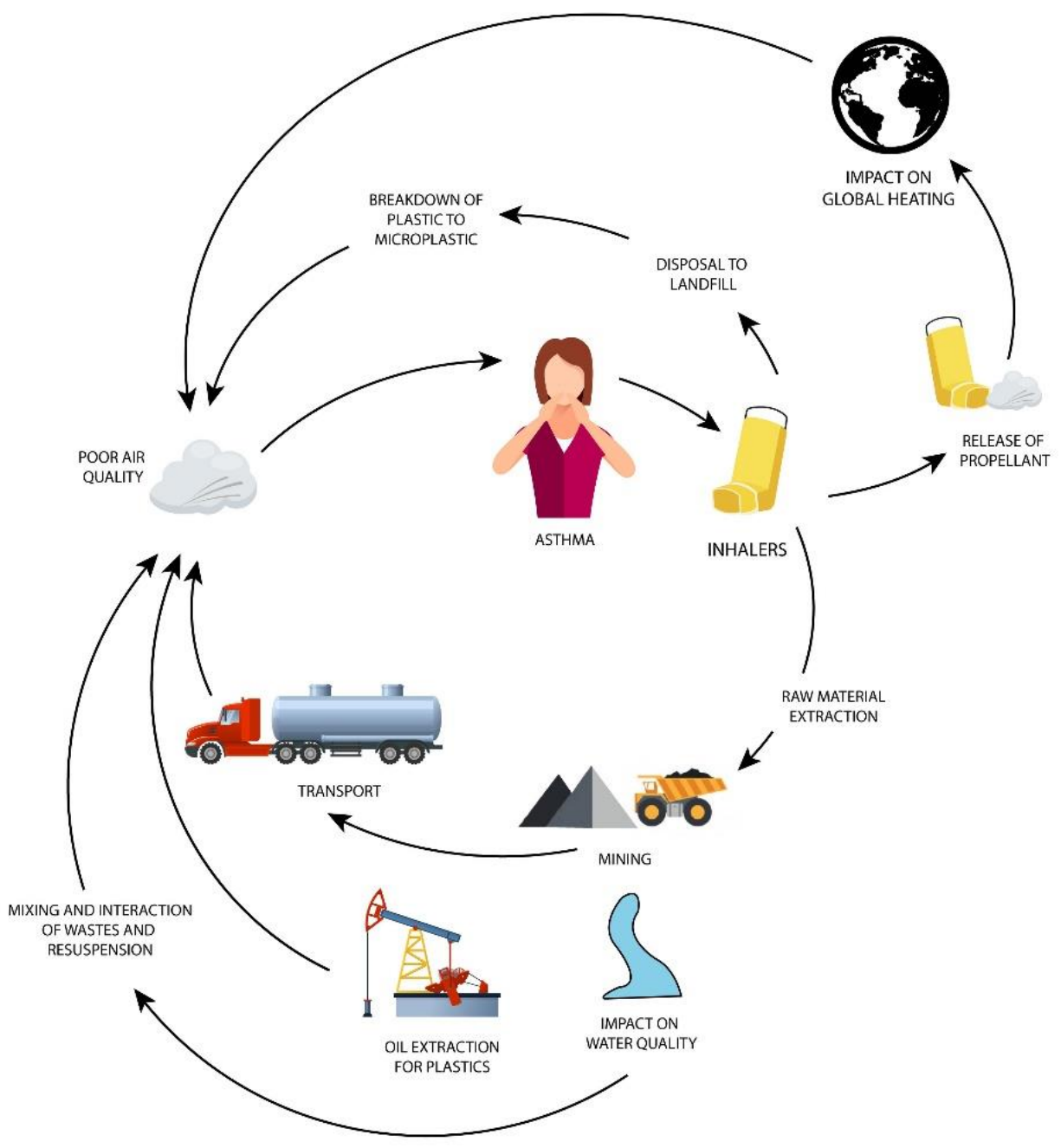

Figure 1. Components of the unnatural cycle of lung disease. (C) Lorna Gibson.

Short-term anthropogenic activities may contribute to long-lasting environmental changes, and not always in a positive way, in much the same way as the eruption of a volcano will bring about long-term geological change.

As an example of an unnatural cycle, we consider the circularity of air quality - lung disease - air quality (Figure 1). This unnatural cycle, the lung disease unnatural cycle, can be described as follows:

Poor air quality provokes a pathophysiological response, increasing asthma and COPD (chronic obstructive pulmonary disease). Those suffering from asthma or COPD may need to use an inhaler. The inhaler requires a manufacturing process using raw materials, some of which must be mined. Mining has an impact on air quality, and also 
contributes to degraded water and land quality. Furthermore, those inhalers which have a gas propellant contribute to greenhouse gases. In countries where there are no appropriate waste collections, there is environmental contamination from leakage of materials in uncontrolled landfill, or from random discarding. In addition, this loss of raw materials into waste provokes a need for further mining, in order to manufacture new inhalers, causing additional decrease in air quality. In addition, there are requirements for transport at various points, which also contribute directly to poor air quality through vehicular emissions, and indirectly through breakdown of vehicle parts such as tyres and brakes, all of which may lead to further health issues, including asthma and COPD.

Thus, we have an unnatural cycle. Whereas many of the natural cycles are broken and need to be mended, this is an unnatural cycle which should be broken in order to rebalance health, both personal and planetary.

\section{The impact of asthma and COPD}

WHO (World Health Organization) has declared asthma a non-communicable disease which can be controlled, and the incidence reduced [1]. The sufferer often loses sleep, school or work time, and is susceptible to other illnesses. Asthma is unpredictable for the sufferer, leading to an inability to plan, and poor quality of life. In addition to the impact on the sufferer, there is an impact on society, through the loss of education and of worker productivity, the cost of medication, and potential hospitalisation. There are many causes of asthma, of which poor air quality is a substantial one. Globally, asthma affected an estimated 262 million people in 2019 and caused 461,000 deaths [1]. While the prevalence is highest in high-income countries, most asthma-related deaths occur in low- and middleincome countries [2]. Poor air quality is now the second cause of death (exceeded only by AIDS) in Africa [3] as non-communicable diseases overtake infections.

COPD, another non-communicable disease, is the third leading cause of deaths worldwide (3.2M in 2019, an $11 \%$ increase from 1990), with $>80 \%$ of these in low- and middle-income countries. It is only half as common as asthma [4]. It causes persistent and progressive respiratory symptoms, including difficulty in breathing, cough and/or phlegm production.

Air pollution is a major contributor to asthma and COPD. Exposure to the Great Smog (or Great Smoke) of London (five days in December 1952; the worst of a number of years and indicative of other polluted cities globally around the same time) killed between 4,000 and 12,000 people, many through COPD [5,6]. But there are consequences other than death. Exposure in the first year of life increased the likelihood of later childhood asthma by $20 \%$ (95\% confidence interval (CI) $3.4 \%$ to $36.4 \%$ ). Evidence is suggestive that in utero exposure at this time led to an $8 \%$ (95\% CI $0 \%$ to $18.2 \%$ ) increase in the likelihood of childhood asthma, with exposure in early life leading to a $10 \%$ increase (95\% CI $0 \%$ to $23.9 \%)$ in the likelihood of adult asthma [7]. The Great Smoke led to improved air quality through legislative action such as the clean air acts in many countries. However, it took until 2021, when, for the first time in UK medical history, a coroner recorded that air pollution had made a significant contribution to the death of a nine-year old child with asthma [8].

The National Health Service in the UK has estimated that one in five people are affected by asthma, with 64 million nurse/general practitioner (family physician) visits each year and over 270 hospitalisations per day $[8,9]$. The financial cost to the patient and health service is not insubstantial: in the UK alone, asthma and COPD cost the National Health Service $£ 3$ billion and $£ 1.9$ billion per annum, respectively [10]. The UK is clearly not the only country affected (Table 1 ).

A widely quoted statement of The International Commonwealth Science Council (although we could not trace the original source) states that in 2010:

"The annual economic cost of premature deaths from air pollution across the countries of the WHO European region stood at US \$1.431 trillion, and the overall annual economic cost of health impacts and mortality from air pollution, including estimates for morbidity costs, stood at US \$1.575 trillion" [11] (p26). 
The incidence and adverse outcomes of asthma are much higher in the most deprived communities when compared to the least deprived [12,13]. This deprivation disparity is worse for COPD [14] and becomes even more important in the light of the current Covid19 pandemic. The impact of the causative agent, SARS-CoV-2 virus, has fallen most heavily on those living in areas of deprivation, where lung function may already be impaired [15].

It is notable that while there are many collaborative health-focused partnerships to improve the respiratory wellbeing of patients, but until very recently similar approaches to air quality have been limited. If the incidence of asthma and COPD is to be reduced, both locally and globally, a collaborative approach to impact and funding needs to be considered, involving health and environmental professionals, at government and intergovernmental levels.

\section{The environmental burden of inhalers}

Asthma inhalers fall into two categories: dry powder, or metered dose (gas powered). Over 35 million metered dose inhalers (70\%) are dispensed annually in the UK for asthma and COPD, representing some $3.5 \%$ of the National Health Service greenhouse gas emissions [16] or $8 \%$ of its carbon footprint [17]. The UK has a doorstep waste collection service, which takes sorted waste to be recycled. Within that system there is no mechanism to collect aerosol containers or allocate an inhaler to a particular waste stream. The majority of inhalers find their way into general household waste and into landfill or to incineration. The recommended route to disposal is for the inhaler to be returned to the pharmacy. The pharmacy can then transfer them to a company which specialises in recycling of waste which is not dealt with through other streams. That, however, requires individuals to make that return. Currently only $0.5 \%$ of inhalers in the UK are recycled [16].

The metered dose inhaler (pMDI) relies on a propellant to expel the powder. The propellants used are powerful global warming gases: hydrofluorocarbon 134a (1,1,1,2-tetrafluoroethane) or hydrofluorocarbon 227 (heptafluoroalkanepropane). Interestingly, the metered dose inhalers are exempted from the European F-gas Regulation [16]. Volumes and gases vary, from $7 \mathrm{ml}$ per puff to $20 \mathrm{ml}$ per puff, depending upon the various manufacturer [24]. Dry powder has a much lower impact: metered dose inhalers have an estimated carbon footprint of $500 \mathrm{~g} \mathrm{CO} 2 \mathrm{eq}$ per dose (annually across the UK $1.34 \mathrm{Mt} \mathrm{CO} 2$ eq., largely from hydrofluorocarbon-134a inhalers [25]), compared to $20 \mathrm{~g}$ for dry powder inhalers [26]. Sweden and most European countries predominantly prescribe the dry powder form [27]. At a local level, Greater Manchester (UK) (2019 population 2.8M) has evaluated the carbon equivalent emissions from the local use of metered dose inhalers, and equated it to switching to LED street lighting across eight of the 10 boroughs or planting three million trees [28].

These and other reports and data focus on the issue of carbon. A rare study on the life cycle of inhalers, although focused on the carbon footprint of the equipment, noted that changing to dry powder inhalers would increase human toxicity, eutrophication and the use of fossil fuel [25]. Indeed, the carbon cycle is a natural cycle which is under threat, and any action which can be taken to lessen the impact on its correct functioning should be taken. However, this single focus misses the bigger picture of the unnatural cycle of lung disease and the resulting impact on natural cycles other than carbon: the impact of material ending up in landfill, the loss of material from production, and the uncontrolled release of greenhouse gases. 
Table 1. Costs of asthma per patient and per year in literature reports.

\begin{tabular}{|c|c|c|c|c|c|c|c|c|c|c|c|c|}
\hline Year & Country & Currency & Total cost & $\begin{array}{l}\text { Prescription } \\
\text { medicines }\end{array}$ & GP visits & In-patient & OPD & A\&E & $\begin{array}{l}\text { Non- } \\
\text { medical }\end{array}$ & Indirect & $\begin{array}{l}\text { Number of } \\
\text { cases }\end{array}$ & Ref \\
\hline $\begin{array}{l}2008- \\
2013\end{array}$ & USA & US\$ & $\begin{array}{l}\text { 3,100 / patient / year; } \\
81.9 \text { billion total } \\
(2013)\end{array}$ & $\begin{array}{l}1830 \text { per } \\
\text { patient pa (4) }\end{array}$ & 640 & $\begin{array}{l}529 \text { mean / } \\
\text { patient stay } \\
\text { (4) }\end{array}$ & $\begin{array}{l}176 \text { / patient / } \\
\text { visit (4) }\end{array}$ & $\begin{array}{l}105 \text { / } \\
\text { patient / } \\
\text { visit }\end{array}$ & $\begin{array}{l}3 \text { billion } \\
\text { total }\end{array}$ & $\begin{array}{l}29 \text { billion } \\
\text { total }\end{array}$ & $\begin{array}{l}40 \text { million pa } \\
(13 \% \\
\text { population })\end{array}$ & {$[18,19]$} \\
\hline 2010 & Iran & US\$ & $\begin{array}{l}\text { 3,100 total; } \\
368 \text { / patient pa }\end{array}$ & $\begin{array}{l}253 / \text { patient } \\
\text { pa }\end{array}$ & & & & & & $\begin{array}{ll}6.49 & / \\
\text { patient / } \\
\text { visit }\end{array}$ & & [20] \\
\hline 2011 & South Korea & US\$ & $\begin{array}{l}\text { Total, } 831 \text { Million: } \\
336 \text { / person average }\end{array}$ & $\begin{array}{l}144.9 \text { million } \\
\text { pa }\end{array}$ & & $\begin{array}{l}61 \text { million } \\
\text { dollars pa }\end{array}$ & $\begin{array}{l}310 \text { million } \\
\text { pa }\end{array}$ & & $\begin{array}{l}831.1 \\
\text { million } \\
\text { pa }\end{array}$ & $\begin{array}{l}103.1 \\
\text { million pa }\end{array}$ & & {$[21]$} \\
\hline 2017 & Europe & Euro & $\begin{array}{l}1,900 \text { / patient pa; } \\
\text { total } 4.3 \text { billion pa }\end{array}$ & $\begin{array}{l}315 \text { mean / } \\
\text { per patient } \\
\text { pa; total } \\
17.2 \text { billion pa }\end{array}$ & $\begin{array}{l}97 \text { mean / } \\
\text { patient }\end{array}$ & & & & & $\begin{array}{l}1783 \text { / } \\
\text { patient }\end{array}$ & $\begin{array}{l}12.2 \text { million } \\
\text { pa }\end{array}$ & {$[18]$} \\
\hline 2017 & Greece & Euro & 2281.8 / patient pa & & & & & & & & & {$[22]$} \\
\hline 2017 & Abu Dhabi & US\$ & 150 / patient & & & & & & & & & [23] \\
\hline 2021 & $\begin{array}{l}\text { United } \\
\text { Kingdom }\end{array}$ & $\begin{array}{l}\text { British } \\
\text { pounds }(£)\end{array}$ & $\begin{array}{l}3 \text { billion asthma; } 1.9 \\
\text { billion COPD, pa }\end{array}$ & & $\begin{array}{l}64 \\
\text { million } \\
\text { pa }\end{array}$ & $\begin{array}{l}270 \text { / day/ } \\
\text { patient }\end{array}$ & & & & & & [10] \\
\hline
\end{tabular}




\section{What happens next?}

The end of life of an inhaler is a debatable endpoint. Theoretically it is the point when all the content has been delivered to the patient for control of symptoms, i.e. when the inhaler is empty. However, in the UK, $£ 300$ Million per annum, a conservative estimate, is spent on prescriptions, including inhalers, which are not utilized [29]. With Asthma UK advocating disposal of an inhaler within six months of it being opened (https://www.asthma.org.uk/advice/inhalers-medicines-treatments/inhalers-and-spacers/reliever/), it is probable that many partly-used inhalers contribute to that figure.

With a focus on circular economy [30-32], the end of life of a product should not be the end of usefulness, nor should it be condemned to landfill nor yet incineration. Incineration has one advantage: when carried out under controlled conditions it can generate energy from waste. Oil can be burned to provide energy for many processes; using it as a basis for the manufacture of plastic, such as is used in inhalers, which is then later incinerated, simply sidesteps its initial combustion, deferring it to a later date. Reclamation of plastic through reprocessing defers it even longer and is preferable.

The landfill option consigns plastics to a hole in the ground, along with the metal components, neither of which break down, but will contribute to leachate. Depending upon how well regulated the landfill is (not all countries have landfill, much less regulated ones) this may be considerably environmentally aggressive. The loss of the inhaler to landfill then means that the manufacture of a replacement inhaler will require virgin materials. The ideal scenario would be for collection of all inhalers, and recovery of materials.

This becomes even more of an imperative as there is now a move towards electronic inhalers [33,34]. The Bluetooth element of the product will potentially move it to a product which is considered to be WEEE (Waste Electrical and Electronic Equipment) with the attendant issues associated with its disposal [35]. The specialist electronics involve rare earth metals, which means the raw materials for the new product now become quite complex in their sourcing.

\section{New products}

A replacement inhaler requires several replacement raw materials: oil for plastic; metals for canisters, and rare earth metals for the electronic components. Each of these materials requires mining (including drilling for oil). Metal production is an energy-intensive process and accounts for $12 \%$ of global energy use plus a material portion of the annual carbon footprint [36]. Producing metals for the green transition in the way they have been produced until now, does little to resolve issues but shifts the environmental and social burden from fossil fuels to metals [37]. Furthermore, mining has multiple environmental impacts which have a direct effect on human health, including particulates released during the breaking of the earth, to contamination of waterways, to adverse health and social impacts [38,39].

As already indicated, smart inhalers will require rare earth elements in their makeup. These are normally found in areas where levels of environmental control are not the most rigorous. Release of rare earth elements into the wider environment can be problematic, and some of the exposed population are quite vulnerable [40]. Only $1 \%$ of rare earth elements is currently recycled [41]: by implication this means that $99 \%$ of new rare earth elements (for whatever purpose) requires further mining of raw material with the attendant problems associated with this. Extraction of rare earth elements also results in the release of associated metals which are not currently required commercially.

Irrespective of the mineral of interest, the mining of material results in waste, or gangue. The make-up of the gangue will be dependent upon the rock being extracted. Vaughan et al advocate the secondary mining of the gangue for rare earth elements, rather than extracting further ore [41]. 
Coal is still the main source of energy production in many areas of the world, and may be used in the manufacture of a new inhaler. In common with other ores already considered, coal gives rise to gangue in addition to the material which is desired. It is estimated that there are 5 billion tonnes of coal gangue in China [42]. Across the UK historical mining activities, including for coal, have led to contamination of local groundwater and surface water [43]. Although there is work underway to control this, because it is historical and the mine-owner no longer exists, a government body has taken responsibility for its control.

The direct emissions are not the only source of contamination; all mining tailings and residues are actively weathered, and interact with the natural environment, giving rise to unintended pollutants [44] (Figure 2). Contaminated water leads to contaminated sediment. Sediments may become resuspended in the atmosphere, either through drying and then becoming wind-blown, or by aerosol effect.

Many countries and organisations have a sustainability strategy, including the UK National Health Service [45]. However, mining is not sustainable. The material being extracted has a long geological timeframe. It is not possible to replace it within the span of one generation, therefore, by definition, it is not sustainable. There are many medical devices of which inhalers are but one; others such as replacement heart valves, replacement joints, and medical equipment such as scanners, also rely on rare earth elements for their functioning. Such medical progress is excellent, and beneficiaries will be grateful for their existence, but it should be remembered that they come at a cost to other members of society.

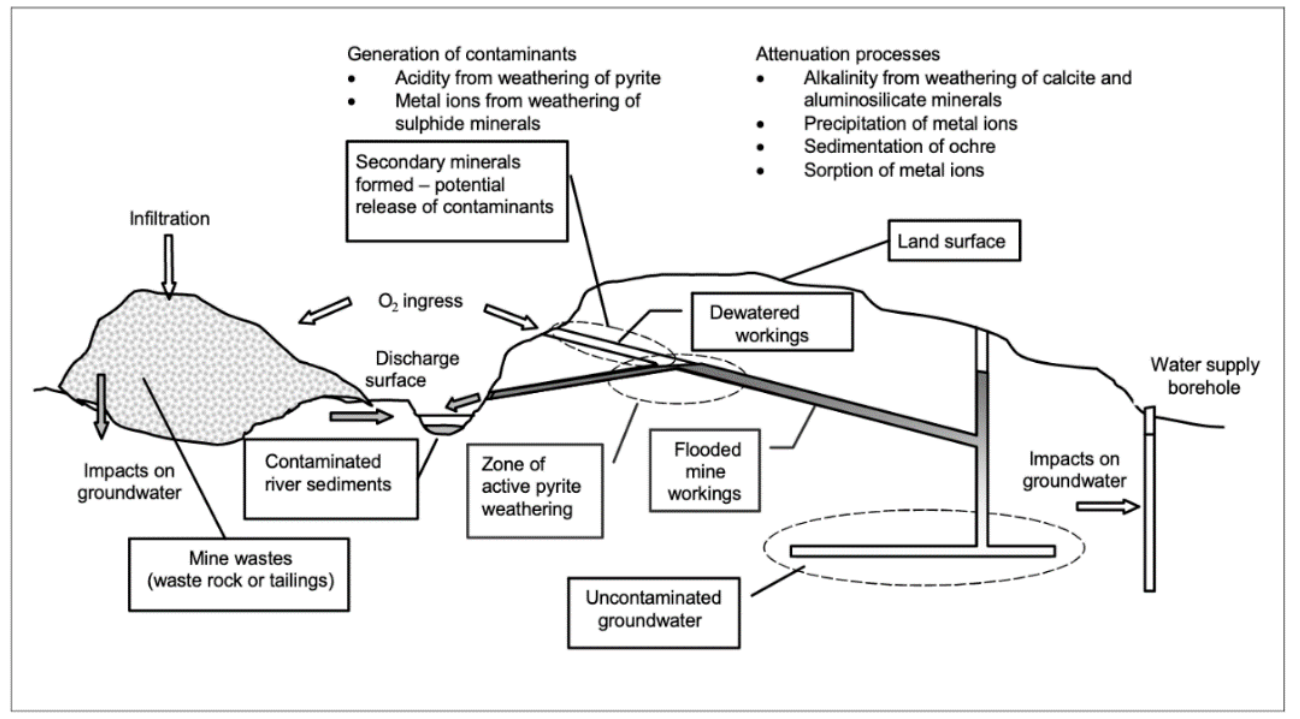

Figure 2. The impacts of mining and chemical actions. Reprinted by permission from Springer Nature: Kluwer Academic Publishers. Mine water: hydrology, pollution, remediation by Younger PL, Banwart SA, Hedin RS. (C) 2002. [44].

\section{Mining problems migrate}

Waste materials from mining do not stay neatly packaged in the locality in which they are generated. Through a combination of windblow, leaching, and physical transfer (on tyres, etc) the unwanted pollutants move away from the mine sites [40,46-48]. As the waste enters the aquatic environment it may be transported several miles through surface water, and ultimately reach the sea.

It is not simply the waste generated by the physical act of breaking and extracting rock which contributes to the waste, but also the general detritus of living, from the mining communities themselves. This may be particularly problematic where there is no clear route for collection of waste. It will include all the waste which is experienced from any 
community: plastics, paper, glass, tins, etc., with whatever contamination they carry with them.

\section{Unintended consequences}

Sharifuzzaman et al. [49] have discussed the nature and mode of contamination of estuarine and coastal waters by metals and chemicals, from anthropogenic activity. As already referenced, waste-water from mining can migrate to estuarine waters. Equally, uncontrolled solid waste can enter surface water and groundwater. This is a global concern. Once the waste material enters the estuarine or marine water, chemistry happens [50]. Whether this is the interaction between metals and seawater [51], plastics and seawater [52] or the behaviour of the sediments themselves [53], the complex and unlooked for interactions are not stable across time [54]. The sediments themselves do not build in a stable manner: they are prone to disruption by both wind and wave action [55].

The importance of this from a health perspective is that as the sediments become resuspended in the atmosphere by wind action, and the oceanic water becomes suspended as aerosol, the particulate matter which is then available to be breathed in is likely to be contaminated in some way, and not a 'simple' particle, with multiple possible adverse health effects beyond asthma and COPD [56,57]. Johanssen et al. [58] have provided excellent descriptions of the formation of problematic aerosols considering widely used detergents. The principle is the same for any chemical which is entrained in the aerosols.

\section{Daily actions.}

It is not only the industrial actions which contribute to the poor air quality. The transport of the goods from one place to another is a direct contributor to poor air quality, by direct emission of products of combustion from the tail pipe. The assumption that the move to electrical energy for their propulsion will resolve the issue is erroneous. Particulates from emissions are only a part of the problem. Products of breakdown of vehicle components, such as brakes, tyres, and windscreen wipers, also contribute to particulates.

In much the same way as waste materials from mining make their way to the oceans, so do products of breakdown from transport. Before this happens, they are simply larger particles of dust by the roadside. As noted earlier, chemistry happens. The various particles begin to break down, but interact with the oil on the road, as well as other particulates. As fallen leaves from trees begin to disintegrate, they too contribute to the particulates in circulation.

The process of breakdown occurs over time. As rain brings down atmospheric waste the various particulates begin to mix in the gutters, into an unpleasant sludge. As the sun dries this out, and it becomes windblown, there is mixing with other, perhaps more recently emitted, atmospheric waste, including plastics [59]. However, historic waste may find its way to this interactive sludge [60]. This material has been shown to not only be respirable, but also biaoccessible once in the body [61]. The fact that this material is globally present should raise alarm bells for human health [56,57,62].

The UK, along with many countries whether rich or poor, has a system of hard surfaced roads, with guttering, and a drainage system for collecting and channelling rainwater. However, responsibilities for street cleaning, drainage clearance, protection of surface water all lie with different authorities. Since 2010, funding in the UK has been reduced and many of these services have been curtailed. This means that roadways may not be swept, and waste materials build up along the roadsides (Figure 3). Many gutters have become choked, weeds have gathered, and as flooding occurs more and more particulate matter accretes. As we have already indicated, these particulates may then become airborne, adversely impacting local residents, with the cost of treatment falling upon the local healthcare provider. Local councils have externalised their environmental costs (reduced street cleansing) and local health providers have externalised their costs too 
(ungoverned disposal of spent inhalers) with the unlooked-for ultimate impact on the asthmatic.

Poor air quality is no respecter of boundaries. The rapid global circulation of contaminated air was illustrated very clearly by the nuclear disasters at Chernobyl, in 1986, and Fukushima [63,64]. Similarly, when Eyjafjallajökull erupted in Iceland in 2010, international airspace was closed for several days [65]. 'Saharan rain' is a phenomenon often observed in northern Europe [66,67]. Each of these is also an indicator of 'what must go up must come down'. Although the latter two examples are not anthropogenic in origin, and are therefore beyond control from an immediate air quality perspective, once they have gone through the 'must come down' element of this cycle, they indicate the global nature of atmospheric contamination and become a part of the general sludge which washes off our windows, buildings, cars and other hard structures, into roads, gutters and drains, to be resuspended in the atmosphere in the next dry spell.

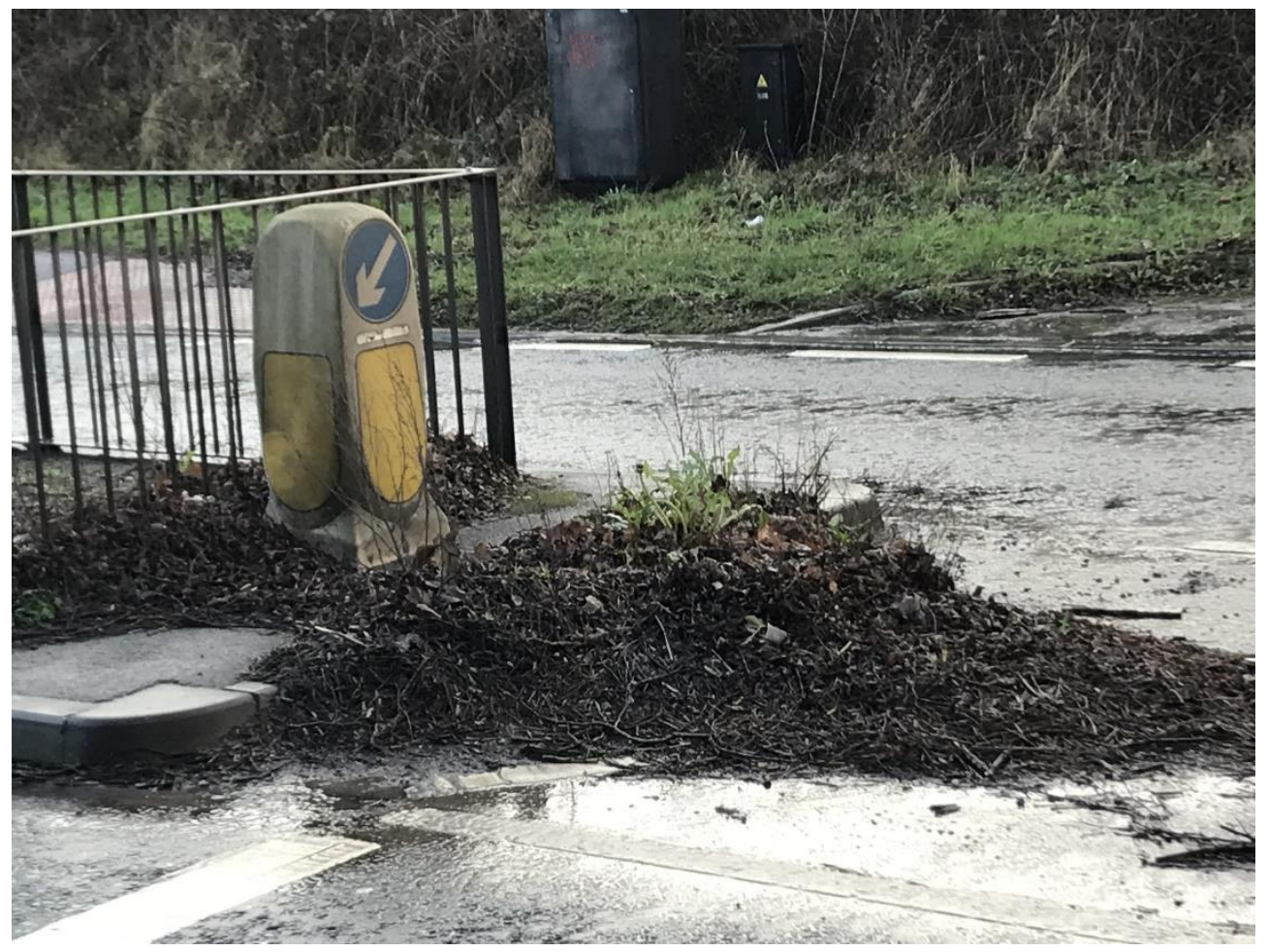

Figure 3. Entrained waste material behind road furniture at an urban setting in the UK. The material comprises a combination of natural leaf litter, sludge and vehicle components. (C) Gillian Gibson.

\section{Who pays? And who benefits?}

Cases of asthma are greatest closest to roads [68]. The reasonable assumption is that this is due to direct traffic emissions. This may be partially true, but the role played by indirect and mixed particulates cannot be ignored. The health service is not responsible for street cleaning. However, the cost of treatment for those who are asthmatic or suffer COPD is borne across many government administrations: the health service for the cost of prescriptions; industry paying sick leave; hospitals for acute care; revenue and customs for loss of taxable income; health insurance providers of private health cover; wider society paying tax to support the above, and loss of contributions towards state pensions. Then there is the heavy cost borne by the individual: loss of work time; loss of family time; loss of school time; the sheer problem of being ill, and possibly for the unfortunate ones the loss of life.

In this survey we have focused on asthma and COPD as a straightforward illustration of the link between the actions of one area of health care impacting upon wider issues of health, across temporal and spatial divides. Asthma is a common illness; most people will 
know of someone who is asthmatic of has COPD, and has need of an inhaler. And this is the point. We have focused upon (too) commonplace illnesses which could be reduced as an 'everyday' presentation through better management: not of the diseases themselves, but of the methods of treatment of the disease; and of environmental interactions.

Circularity of thinking would be helpful, but so too would circularity of funding. However, to achieve this there would need to be a recognition that when cost benefit analysis of a project is undertaken, the cost benefit analysis of inaction also needs to be compared. The benefit may not always accrue to the provider of funds, which is why a means of evaluation is important. The US National Research Council recognises collaboration is needed for success in this [69].

The World Bank has referenced the Global Burden of Disease study (https://www.healthdata.org/gbd/2019) [1] as being an imperative to act on air quality, noting that the global cost of health damages associated with exposure to air pollution is $\$ 8.1$ trillion, equivalent to 6.1 percent of global GDP [70].

The financial impact is but one side of the equation; on the other is the impact on lives: 6.4 million premature deaths and 93 billion days lived with illness in 2019 [70] are very big numbers. They are certainly bigger than for the COVID-19 pandemic, yet the latter has attracted global concern and a global approach to tackling the problem.

A quarter of a century ago Arrow et al. [71] considered the importance of cost benefit analysis in evaluation of environmental, health, and safety regulation, citing the example of the need to implement costly regulation to resolve the problem of the hole in the ozone layer, as a global problem of great magnitude. The problem of cases of asthma and COPD with their associated costs, and loss of productivity, would suggest that a similar approach is required to resolve this global issue. This requires breaking down the silos of funding, destroying empires of protectionism, and reconsider the problem from the bottom up:

- what is the problem? - increasing cases of asthma and COPD

- $\quad$ what caused the problem? - poor air quality

- $\quad$ what did we do about it? - prescribed inhalers to treat the symptoms

- what did this achieve? - possible improvement of patient condition; definite consumption of raw materials; definite creation of a difficult-to-manage waste stream

- $\quad$ has the problem been resolved? - no, it has been exacerbated

- $\quad$ why did this not work? - because political will and money need to be invested in the right place

In other words, collaboration needs to be applied across all sectors, and across countries, to gain the right outcome, which would be improved health, and with it the improved wealth of countries.

\section{Bigger problems}

Global heating and the associated climate change, each of which impact asthma directly [72], have been described as 'super wicked problems'. These problems have four key features: (1) time is running out; (2) those who cause the problem also seek to provide a solution; (3) the central authority needed to address it is weak or non-existent; and, (4) partly as a result, policy responses discount the future irrationally. "These four features combine to create a policy-making tragedy where traditional analytical techniques are ill equipped to identify solutions, even when it is well recognized that actions must take place soon to avoid catastrophic future impacts" [73]. Furthermore, policy is only effective when it is acted upon: a mechanism to evaluate outcomes is required if success is to be assured.

Although it is recognised that global heating is a threat to health [74], that impact on health has not yet been flagged up as a 'super wicked' problem. Yet clearly it shares the attributes described above. The interconnectivity of poor air quality and poor health is extensive, and extensively reported upon [75]. It would seem that it is a prime candidate 
to be classified as a super wicked problem, and to be treated with a central thrust of improving air quality at a global level.

John Muir said, "When we try to pick out anything by itself, we find it hitched to everything else in the Universe" [76] (Chapter 6, July 27). That is very true of all our natural cycles. It is also very true of this artificially constructed unnatural cycle. And probably of others. In order for the unnatural cycle to be broken, the threads need to be identified, and the actors attached to the various threads drawn into the central web, from which collaboration begins. But first there needs to be a recognition that we cannot unhitch ourselves or leave it to others to find the remedies for a modern 'super wicked' problem.

\section{Conclusion}

Despite COVID-19 having had a catastrophic effect at a global level over 2020-2022, it has also illuminated the differences between the 'haves' and 'have nots', with the burden of disease falling disproportionally more on those with lower incomes. This is the same as for those struggling with the daily impact of living with asthma and COPD. It has, however, demonstrated the speed with which governments can act, when necessary. It has demonstrated a willingness to support those who are struggling. There has been discussion (though not yet a clear demonstration) of intercontinental support. There has also been the awakening of realisation that poor air quality has played a major role in this impact. Now may be a pivotal moment at which governments, policy makers and funders can act collectively to break the unnatural lung disease cycle conclusively.

Author Contributions: GG and AGS conceived the paper; GG wrote the first draft and AGS revised it. Both authors read and agreed the final version.

Funding: This research received no external funding.

Acknowledgments: The authors acknowledge the help of Lorna Gibson https://tootsdesign.co.uk/ in the preparation of Figure 1. AGS acknowledges the continuing support of Khaliq O Malik.

Conflicts of Interest: GG runs the consulting and training company Gibson Consulting and Training. The remaining authors declare that the research was conducted in the absence of any commercial or financial relationships that could be construed as a potential conflict of interest. The views presented in this publication are those of the authors, and do not necessarily reflect those of their employers.

\section{References}

1. Vos, T.; Lim, S.S.; Abbafati, C.; Abbas, K.M.; Abbasi, M.; Abbasifard, M.; Abbasi-Kangevari, M.; Abbastabar, H.; Abd-Allah, F.; Abdelalim, A.; et al. Global burden of 369 diseases and injuries in 204 countries and territories, 1990-2019: a systematic analysis for the Global Burden of Disease Study 2019. The Lancet 2020, 396, 1204-1222. doi:10.1016/S0140-6736(20)30925-9

2. To, T.; Stanojevic, S.; Moores, G.; Gershon, A.S.; Bateman, E.D.; Cruz, A.A.; Boulet, L.-P. Global asthma prevalence in adults: findings from the cross-sectional World Health Survey. BMC Public Health 2012, 12, 1-8. doi:10.1186/1471-2458-12-204

3. Fisher, S.; Bellinger, D.C.; Cropper, M.L.; Kumar, P.; Binagwaho, A.; Koudenoukpo, J.B.; Park, Y.; Taghian, G.; Landrigan, P.J. Air pollution and development in Africa: Impacts on health, the economy, and human capital. Lancet Planet. Health 2021, 5, e681-e688. doi:10.1016/S2542-5196(21)00201-1

4. GBD 2015 Chronic Respiratory Disease Collaborators. Global, regional, and national deaths, prevalence, disability-adjusted life years, and years lived with disability for chronic obstructive pulmonary disease and asthma, 1990-2015: A systematic analysis for the Global Burden of Disease Study 2015. Lancet Respir. Med. 2017, 5, 691-706, doi:10.1016/S2213-2600(17)30293-X

5. Hunt, A.; Abraham, J.L.; Judson, B.; Berry, C.L. Toxicologic and Epidemiologic clues from the characterization of the 1952 London smog fine particulate matter in archival autopsy lung tissues. Environ. Health. Perspect. 2003, 111, 1209-1214 doi:10.1289/ehp.6114

6. Bell, M.L.; Davis, D.L.; Fletcher, T. A Retrospective Assessment of Mortality from the London Smog Episode of 1952: The Role of Influenza and Pollution. Environ. Health Perspect. 2004, 112, 6-8. doi:10.1289/ehp.6539

7. Bharadwaj, P.; Zivin, J.G.; Mullins, J.T.; Neidell, M. Early-Life exposure to the Great Smog of 1952 and the development of asthma. Am. J. Respir. Crit. Care Med. 2016, 194, 1475-1482. doi:10.1164/rccm.201603-0451OC

8. Mukherjee, M.; Stoddart, A.; Gupta, R.P.; Nwaru, B.I.; Farr, A.; Heaven, M.; Fitzsimmons, D.; Bandyopadhyay, A.; Aftab, C.; Simpson, C.R.; et al. the epidemiology, healthcare and societal burden and costs of asthma in the uk and its member nations: Analyses of standalone and linked national databases. BMC Med. 2016, 14, 1-15. doi:10.1186/s12916-016-0657-8 
9. Cumella, A.; Haque, A. On the edge. How inequality affects people with asthma. Asthma UK: London, 2018.

10. NHS England. Respiratory Disease Available online: https://www.england.nhs.uk/ourwork/clinical-policy/respiratory-disease/ (accessed on 14 October 2021).

11. World Health Organization. Economic cost of the health impact of air pollution in Europe: Clean air, health and wealth; World Health Organization: Geneva, 2015.

12. Simons, E.; Dell, S.D.; Moineddin, R.; To, T. Neighborhood material deprivation is associated with childhood asthma development: Analysis of prospective administrative data. Can. Respir. J. 2019, e6808206. doi:10.1155/2019/6808206

13. Alsallakh, M.A.; Rodgers, S.E.; Lyons, R.A.; Sheikh, A.; Davies, G.A. Association of socioeconomic deprivation with asthma care, outcomes, and deaths in Wales: A 5-year national linked primary and secondary care cohort study. PLOS Med. 2021, 18, e1003497. doi:10.1371/journal.pmed.1003497

14. Collins, P.F.; Stratton, R.J.; Kurukulaaratchy, R.J.; Elia, M. Influence of deprivation on health care use, health care costs, and mortality in COPD. Int. J. Chron. Obstruct. Pulmon. Dis. 2018, 13, 1289-1296. doi:10.2147/COPD.S157594

15. Bambra, C.; Riordan, R.; Ford, J.; Matthews, F. The COVID-19 pandemic and health inequalities. J. Epidemiol. Community Health 2020, 74, 964-968. doi:10.1136/jech-2020-214401

16. Environmental Audit Committee. UK Progress on Reducing F-Gas Emissions. Fifth Report of Session 2017-19; House of Commons: London, 2018.

17. Hillman, T.; Mortimer, F.; Hopkinson, N.S. Inhaled drugs and global warming: Time to shift to dry powder inhalers. BMJ 2013, 346, f3359. doi:10.1136/bmj.f3359

18. Nunes, C.; Pereira, A.M.; Morais-Almeida, M. Asthma costs and social impact. Asthma Res. Pract. 2017, 3, 1. doi:10.1186/s40733016-0029-3

19. Nurmagambetov, T.; Kuwahara, R.; Garbe, P. The economic burden of asthma in the United States, 2008-2013. Ann. Am. Thorac. Soc. 2018, 15, 348-356. doi:10.1513/AnnalsATS.201703-259OC

20. Sharifi, L.; Dashti, R.; Pourpak, Z.; Fazlolahhi, M.R.; Movahedi, M.; Chavoshzadeh, Z.; Soheili, H.; Bokair, S.; Kazemnejad, A.; Moin, M. Economic burden of pediatric asthma: Annual cost of disease in Iran. Iran. J. Public Health 2018, 47, $256-263$.

21. Lee, Y.-H.; Yoon, S.-J.; Kim, E.-J.; Kim, Y.-A.; Seo, H.-Y.; Oh, I.-H. Economic burden of asthma in Korea. Allergy Asthma Proc. 2011, 32, e35-e40. doi:10.2500/aap.2011.32.3479

22. Souliotis, K.; Kousoulakou, H.; Hillas, G.; Bakakos, P.; Toumbis, M.; Loukides, S.; Vassilakopoulos, T. Direct and indirect costs of asthma management in Greece: An expert panel approach. Front. Public Health 2017, 0, doi:10.3389/fpubh.2017.00067

23. Alzaabi, A.; Alseiari, M.; Mahboub, B. Economic burden of asthma in Abu Dhabi: A retrospective study. Clin. Outcomes Res. CEOR 2014, 6, 445-450. doi:10.2147/CEOR.S68920

24. Sellers, W.F.s. asthma pressurised metered dose inhaler performance: propellant effect studies in delivery systems. Allergy Asthma Clin. Immunol. 2017, 13, 1-7. doi:10.1186/s13223-017-0202-0

25. Jeswani, H.K.; Azapagic, A. Life cycle environmental impacts of inhalers. J. Clean. Prod. 2019, 237, 117733. doi:10.1016/j.jclepro.2019.117733

26. Janson, C.; Henderson, R.; Löfdahl, M.; Hedberg, M.; Sharma, R.; Wilkinson, A.J.K. Carbon footprint impact of the choice of inhalers for asthma and COPD. Thorax 2020, 75, 82-84. doi:10.1136/thoraxjnl-2019-213744

27. Lavorini, F.; Corrigan, C.J.; Barnes, P.J.; Dekhuijzen, P.R.N.; Levy, M.L.; Pedersen, S.; Roche, N.; Vincken, W.; Crompton, G.K. Retail sales of inhalation devices in European countries: So much for a global policy. Respir. Med. 2011, 105, $1099-1103$. doi:10.1016/j.rmed.2011.03.012

28. Atherton, M. Environmental Impact of Inhalers; Low Carbon Hub: Oxford, 2017.

29. Taylor, D. Evaluation of the scale, causes and costs of waste medicines. Final Report; University of London School of Pharmacy: London, 2010. ISBN 978-0-902936-20-1.

30. UK Government. Circular Economy Package Policy Statement. Available online: https://www.gov.uk/government/publications/circular-economy-package-policy-statement/circular-economy-package-policy-statement (accessed on 1 September 2021).

31. European Commission. Circular Economy Action Plan. Available online: https://ec.europa.eu/environment/strategy/circulareconomy-action-plan_en (accessed on 1 September 2021).

32. Circular Change. The State of the Circular Economy in America - The First Report. Available online: https://www.circularchange.com/news/the-state-of-the-circular-economy-in-america-the-first-report (accessed on 1 September 2021).

33. Alshabani, K.; Attaway, A.A.; Smith, M.J.; Majumdar, U.; Rice, R.; Han, X.; Wang, X.; Hatipoğlu, U. Electronic inhaler monitoring and healthcare utilization in chronic obstructive pulmonary disease. J. Telemed. Telecare 2020, 26, $495-503$. doi:10.1177/1357633X19850404

34. Attaway, A.H.; Alshabani, K.; Bender, B.; Hatipoğlu, U.S. The utility of electronic inhaler monitoring in COPD management: Promises and challenges. Chest 2020, 157, 1466-1477. doi:10.1016/j.chest.2019.12.034

35. European Commission. Waste from electrical and electronic equipment (WEEE). Available online: https://ec.europa.eu/environment/topics/waste-and-recycling/waste-electrical-and-electronic-equipment-weee_en (accessed on 1 September 2021).

36. US Energy Information Administration (EIA). The basic metals industry is one of the world's largest industrial energy users. Available online: https://www.eia.gov/todayinenergy/detail.php?id=38392 (accessed on 6 November 2021).

37. Paulikas, D.; Katona, S.; Ilves, E.; Stone, G.; O'Sullivan, A. Where should metals for the green transition come from? Comparing environmental, social, and economic impacts of supplying base metals from land ores and seafloor polymetallic nodules; LCA White Paper, Technical Report; 2020. 
38. Entwistle, J.A.; Hursthouse, A.S.; Marinho Reis, P.A.; Stewart, A.G. Metalliferous mine dust: Human health impacts and the potential determinants of disease in mining communities. Curr. Pollut. Rep. 2019, 5, 67-83. doi:10.1007/s40726-019-00108-5

39. Stewart, A.G. Mining is bad for health: A voyage of discovery. Environ. Geochem. Health 2020, 42, 1153-1165. doi:10.1007/s10653019-00367-7

40. Tian, S.; Liang, T.; Li, K.; Wang, L. Source and path identification of metals pollution in a mining area by PMF and rare earth element patterns in road dust. Sci. Total Environ. 2018, 633, 958-966. doi:10.1016/j.scitotenv.2018.03.227

41. Vaughan, J.; Tungpalan, K.; Parbhakar-Fox, A.; Fu, W.; Gagen, E.J.; Nkrumah, P.N.; Southam, G.; van der Ent, A.; Erskine, P.D.; Gow, P.; et al. Toward closing a loophole: recovering rare earth elements from uranium metallurgical process tailings. JOM 2021, 73, 39-53. doi:10.1007/s11837-020-04451-7

42. Jiang, X.; Lu, W.X.; Zhao, H.Q.; Yang, Q.C.; Yang, Z.P. Potential ecological risk assessment and prediction of soil heavy-metal pollution around coal gangue dump. Nat. Hazards Earth Syst. Sci. 2014, 14, 1599-1610. doi:10.5194/nhess-14-1599-2014

43. Johnson, D.; Potter, H.; Jones, C.; Rolley, S.; Watson, I.; Pritchard, J. Abandoned Mines and the Water Environment; Environment Agency: Bristol, 2008.

44. Younger, P.L.; Banwart, S.A.; Hedin, R.S. Mine Water: Hydrology, Pollution, Remediation; Environmental pollution; Kluwer Academic Publishers: Dordrecht ; Boston, 2002; ISBN 978-1-4020-0137-6.

45. Mazzotta, M. Sustainable Development Management Plan for NHS England 2018-2020; NHS England: UK, 2018.

46. Gupta, S.K.; Nikhil, K. Ground water contamination in coal mining areas: A critical review. Int. J. Eng. Appl. Sci. 2016, 3, 69-74.

47. Fayiga, A.O.; Ipinmoroti, M.; Chirene, T. Environmental pollution in Africa. Environ. Dev. Sustain. 2017, $20,41-73$. doi:10.1007/s10668-016-9894-4

48. Gál, J.; Hursthouse, A.; Tatner, P.; Stewart, F.; Welton, R. Cobalt and secondary poisoning in the terrestrial food chain: Data review and research gaps to support risk assessment. Environ. Int. 2008, 34, 821-838. doi:10.1016/j.envint.2007.10.006

49. Sharifuzzaman, S.M.; Rahman, H.; Ashekuzzaman, S.M.; Islam, M.M.; Chowdhury, S.R.; Hossain, M.S. Heavy Metals Accumulation in Coastal Sediments. In Environmental Remediation Technologies for Metal-Contaminated Soils. In Environmental Remediation Technologies for Metal-Contaminated Soils; Hasegawa, H., Rahman, I.Md.M., Rahman, M.A., Eds.; Springer Japan: Tokyo, 2016; pp. 21-42. ISBN 978-4-431-55758-6.

50. Zbyszewski, M.; Corcoran, P.L. Distribution and degradation of fresh water plastic particles along the beaches of Lake Huron, Canada. Water. Air. Soil Pollut. 2011, 220, 365-372. doi:10.1007/s11270-011-0760-6

51. Vidal-Durà, A.; Burke, I.T.; Stewart, D.I.; Mortimer, R.J.G. Reoxidation of estuarine sediments during simulated resuspension events: Effects on nutrient and trace metal mobilisation. Estuar. Coast. Shelf Sci. 2018, 207, 40-55. doi:10.1016/j.ecss.2018.03.024

52. Yokota, K.; Waterfield, H.; Hastings, C.; Davidson, E.; Kwietniewski, E.; Wells, B. Finding the missing piece of the aquatic plastic pollution puzzle: interaction between primary producers and microplastics. Limnol. Oceanogr. Lett. 2017, 2, 91-104. doi:10.1002/lol2.10040

53. Valipour, R.; Boegman, L.; Bouffard, D.; Rao, Y.R. Sediment resuspension mechanisms and their contributions to high-turbidity events in a large lake. Limnol. Oceanogr. 2017, 62, 1045-1065. doi:10.1002/lno.10485

54. Kerfoot, W.C.; Urban, N.; Jeong, J.; MacLennan, C.; Ford, S. Copper-Rich “halo" off Lake Superior's Keweenaw Peninsula and how mass mill tailings dispersed onto tribal lands. J. Gt. Lakes Res. 2020, 46, 1423-1443. doi:10.1016/j.jglr.2020.07.004

55. Kalnejais, L.H.; Martin, W.R.; Signell, R.P.; Bothner, M.H. Role of sediment resuspension in the remobilization of particulatephase metals from coastal sediments. Environ. Sci. Technol. 2007, 41, 2282-2288. doi:10.1021/es061770z

56. He, T.; Jin, L.; Li, X. On the Triad of air particulate pollution, pathogenic bioaerosols, and lower respiratory infection. Environ. Geochem. Health 2021, 1-11. doi:10.1007/s10653-021-01025-7

57. Lelieveld, J.; Evans, J.S.; Fnais, M.; Giannadaki, D.; Pozzer, A. The contribution of outdoor air pollution sources to premature mortality on a global scale. Nature 2015, 525, 367-371. doi:10.1038/nature15371

58. Johansson, J.H.; Salter, M.E.; Navarro, J.C.A.; Leck, C.; Nilsson, E.D.; Cousins, I.T. Global transport of perfluoroalkyl acids via sea spray aerosol. Environ. Sci. Process. Impacts 2019, 21, 635-649. doi:10.1039/C8EM00525G

59. Allen, S.; Allen, D.; Phoenix, V.R.; Le Roux, G.; Durántez Jiménez, P.; Simonneau, A.; Binet, S.; Galop, D. Atmospheric transport and deposition of microplastics in a remote mountain catchment. Nat. Geosci. 2019, 12, 339-344. doi:10.1038/s41561-019-0335-5

60. Potgieter-Vermaak, S.; Rotondo, G.; Novakovic, V.; Rollins, S.; Van Grieken, R. Component-specific toxic concerns of the inhalable fraction of urban road dust. Environ. Geochem. Health 2012, 34, 689-696. doi:10.1007/s10653-012-9488-5

61. Patinha, C.; Durães, N.; Sousa, P.; Dias, A.C.; Reis, A.P.; Noack, Y.; Ferreira da Silva, E. Assessment of the influence of trafficrelated particles in urban dust using sequential selective extraction and oral bioaccessibility tests. Environ. Geochem. Health 2015, 37, 707-724. doi:10.1007/s10653-015-9713-0

62. Amato-Lourenço, L.F.; dos Santos Galvão, L.; de Weger, L.A.; Hiemstra, P.S.; Vijver, M.G.; Mauad, T. An emerging class of air pollutants: Potential effects of microplastics to respiratory human health? Sci. Total Environ. 2020, 749, 141676. doi:10.1016/j.scitotenv.2020.141676

63. UNSCEAR. Sources, effects and risks of ionizing radiation. United Nations Scientific Committee on the Effects of Atomic Radiation 1988 Report to the General Assembly, with Annexes; United Nations: New York, NY, 1988.

64. Masson, O.; Baeza, A.; Bieringer, J.; Brudecki, K.; Bucci, S.; Cappai, M.; Carvalho, F.P.; Connan, O.; Cosma, C.; Dalheimer, A.; et al. Tracking of airborne radionuclides from the damaged Fukushima Dai-Ichi nuclear reactors by European networks. Environ. Sci. Technol. 2011, 45, 7670-7677. doi:10.1021/es2017158 
65. Eurocontrol. Ash-cloud of April and May 2010: Impact on air traffic; European Organisation for the Safety of Air Navigation: Brussels, 2010.

66. Harrison, R.G.; Nicoll, K.A.; Marlton, G.J.; Ryder, C.L.; Bennett, A.J. Saharan dust plume charging observed over the UK. Environ. Res. Lett. 2018, 13, 054018. doi:10.1088/1748-9326/aabcd9

67. Harrison, R.G.; Nicoll, K.A.; Marlton, G.J.; Ryder, C.L.; Bennett, A.J. Corrigendum: Saharan dust plume charging observed over the UK 2018 (Environ. Res. Lett. 13 054018). Environ. Res. Lett. 2018, 13, 109502. doi:10.1088/1748-9326/aae591

68. Gauderman, W.J.; Vora, H.; McConnell, R.; Berhane, K.; Gilliland, F.; Thomas, D.; Lurmann, F.; Avol, E.; Kunzli, N.; Jerrett, M.; et al. Effect of exposure to traffic on lung development from 10 to 18 years of age: A cohort study. Lancet 2007, 369, 571-577. doi:10.1016/S0140-6736(07)60037-3

69. National Research Council. Science for environmental protection: The road ahead; The National Academies Press: Washington, DC, 2012. ISBN 978-0-309-26489-1.

70. World Bank. The global health cost of PM2.5 air pollution: A case for action beyond 2021; World Bank: Washington, DC, 2021. ISBN 978-1-4648-1816-5.

71. Arrow, K.J.; Cropper, M.L.; Eads, G.C.; Hahn, R.W.; Lave, L.B.; Noll, R.G.; Portney, P.R.; Russell, M.; Schmalensee, R.; Smith, V.K.; et al. Is there a role for benefit-cost analysis in environmental, health and safety regulation? Science 1996, 272, $221-222$.

72. Beggs, P.J.; Bambrick, H.J. Is the global rise of asthma an early impact of anthropogenic climate change? Environ. Health Perspect. 2005, 113, 915-919. doi:https://doi.org/10.1289/ehp.7724

73. Levin, K.; Cashore, B.; Bernstein, S.; Auld, G. Overcoming the tragedy of super wicked problems: Constraining our future selves to ameliorate global climate change. Policy Sci. 2012, 45, 123-152. doi:10.1007/s11077-012-9151-0

74. Costello, A.; Montgomery, H.; Watts, N. Climate change: The challenge for healthcare professionals. BMJ 2013, 347 , f6060. doi:10.1136/bmj.f6060

75. Finch, C. The role of global air pollution in aging and disease, 1st ed.; Academic Press: London, 2018. ISBN 978-0-12-813102-2.

76. Muir, J. My First Summer in the Sierra; Houghton Mifflin: Boston MA, 1911. ISBN 9780217618649. 